\title{
Clinical and laboratory characterization of adult T-cell leukemia/lymphoma in patients from Salvador, Bahia
}

Caracterização clínica e laboratorial da leucemia/linfoma de células T do adulto em pacientes de Salvador, Bahia

Evelyn Keila dos Santos Bomfim¹, Mariane Melo dos Santos², Songeli Menezes Freire ${ }^{1,2}$, Roberto José Meyer ${ }^{1,2}$ Alex José Leite Torres ${ }^{1,2}$

\begin{abstract}
ATLL is a malignant and aggressive leukemia whose survival time is limited. It is known that $5 \%$ of individuals infected with HTLV-1, after many years of latency, may develop this disease. The mechanisms by which the evolution of clinical conditions occurs are unknown, and in Brazil there are few studies about ATLL, this some important themes will be addressed in this study. Thus, the objective of this study is to characterize the epidemiological and immunophenotypic profile of patients diagnosed with ATLL, attended at an oncohematological reference center in Salvador, Bahia, in the period between 2010-2018. The methodology consisted of a descriptive, retrospective of time series study, which cases of ATLL were collected from reports belonging a reference laboratory and of medical reports available from Com-HUPES. These data were treated and analyzed statistically, being observed that the majority of cases were female and that a large part have the most aggressive clinical condition Although the literature reports that ATLL clinical condition are always considered as severe, in this study it was observed that patients can achieve long survival in good clinical conditions, according to the treatment administered. In view of the available results, it is possible to conclude that exist a broad distinction between the clinical and molecular forms, being may be an important indicator of the evolution of ATLL.
\end{abstract}

Keywords: Adult T-cell leukemia-lymphoma; HTLV-1; Immunophenotyping; treatment; survival

\footnotetext{
1.Federal University of Bahia, Postgraduate Program in Immunology - Salvador - Bahia - Brazil.

2. Federal University of Bahia, Laboratory of Immunology and Molecular Biology - Salvador - Bahia - Brazil.

Financial support: none to declare.

Conflicts of interest: The authors declare no conflict of interest relevant to this manuscript.

Correspondence author: Alex José Leite Torres.

E-mail: ajltorres@gmail.com / ajtorres@ufba.br
} 


\section{RESUMO}

Leucemia/linfoma de células T do adulto (L/LTA) é uma leucemia maligna e agressiva, cujo tempo de sobrevivência é limitado. Sabe-se que $5 \%$ dos indivíduos infectados pelo vírus T-linfotrópico humano tipo 1 (HTLV-1), após muitos anos de latência, podem desenvolver essa doença. Os mecanismos pelos quais ocorre a evolução das condições clínicas são desconhecidos, e no Brasil existem poucos estudos sobre L/LTA, alguns temas importantes serão abordados neste estudo. Assim, o objetivo deste estudo é caracterizar o perfil epidemiológico e imunofenotípico dos pacientes com diagnóstico de L/LTA, atendidos em um centro de referência em oncohematologia em Salvador, Bahia, no período de 20102018. A metodologia consistiu em um estudo descritivo e retrospectivo de séries temporais, cujos casos de L/LTA foram coletados em laudos pertencentes a um laboratório de referência e em laudos médicos disponibilizados pelo Com-HUPES. Esses dados foram tratados e analisados estatisticamente, sendo observado que a maioria dos casos era do sexo feminino e que grande parte apresenta o quadro clínico mais agressivo. Apesar de a literatura relatar que as condições clínicas do L/LTA são sempre consideradas graves, neste estudo observou-se que os pacientes podem alcançar longa sobrevida em boas condições clínicas, de acordo com o tratamento administrado. Diante dos resultados disponíveis, é possível concluir que existe uma ampla distinção entre as formas clínica e molecular, podendo ser um importante indicador da evolução da L/LTA.

Descritores: Sobrevivência; Leucemia-linfoma de células T adultas; Vírus T-linfotrópico humano tipo 1; Imunofenotipagem; Resultado do tratamento.

\section{INTRODUCTION}

The adult T-cell leukaemia / lymphoma (ATLL) is a serious haematological disease associated with Human Type 1 T-cell Lymphotropic Virus infection (HTLV-1) ${ }^{1}$. The HTLV-1 has the ability to transform and immortalize $\mathrm{T}$ cells, however, only about $5 \%$ of infected individuals develop ATLL, usually manifesting clinical symptoms after a prolonged period of viral latency ${ }^{2-4}$.

This disease has an unpleasant prognosis, rapid clinical evolution and diverse manifestations, and is commonly characterized by short survival time and poor response to chemotherapy, important points that are distinguished from other types of leukemias ${ }^{5}$. Differentiation between anomalous and normal cells is based on phenotypic patterns that are distinct in these cell populations 6 . Therefore, most patients that develop ATLL exhibit the phenotype mature CD4 $+\mathrm{T}$ cell and express some surface markers, partial loss or complete absence of others ${ }^{7,8}$.

It is estimated that approximately 20 million of people worldwide are infected for this retrovirus that ATLL causer and in Brazil there are several regions that are classified as endemic for this virus ${ }^{1}$. In the north and northeast of Brazil there are high percentages of seroprevalence for HTLV-1 and Bahia occupies second position in the national ranking with $0.0094 \%$ of cases $^{9,10}$.

\section{METHODOLOGY}

This is a descriptive, retrospective, time series study, obtained from the database available at the diagnostic service of the Laboratório de Imunologia e biologia molecular of the Instituto de Ciências da
Saúde (ICS) of the Universidade Federal da Bahia (UFBA) from 2010 to 2018. The data were treated from the analysis of reports performed by the technique of flow cytometry immunophenotyping, available by the lab.

Based on the data from the reports, the search for electronic clinical records was initiated through the Sistema de Monitoramento e Avaliação dos Resultados do Programa Nacional Telessaúde Brasil Redes (SMART), made available by Complexo Hospitalar Universitário Professor Edgard Santos (Com-HUPES) for additional data.

This study, information was collected and the evaluated data were: demographic variables (sex; age of diagnosis, biochemical profile, clinical form, proportional distribution of morbidity and treatment used); biochemical profile (calcium, creatinine, lactate dehydrogenase - LDH, magnesium, potassium, sodium, urea); clinical form; HTLV-1 serology; clinical form of ATLL; leukogram; immunophenotyping (used markers - CD45; CD2; CD3; CD4; CD5; CD7; CD25; CD8).

Seropositivity for HTLV-1 was verified for all clinical records of patients, diagnosis was based on serological evidence of HTLV-1by enzyme-linked immunosorbent assay and confirmed by western blot test, all patients included in the study had positive serology for this two test. The clinical form of each patient was classified according to the Shimoyama criteria and the addition of Bittencourt's PCT form suggestion ${ }^{11}$.

The immunogenotyping made available in the reports was performed with monoclonal antibodies conjugated with differentfluorochromes, thereagents 
used were validated by the laboratory as determined by RDC 302/ 2005 - ANVISA. The anomalous cells were acquired by flow cytometry (CMF) through the FACSCalibur-BD and FACSCanto II - BD cytometers and the Infinicyt тм Cytognos ${ }^{\circledR}$ Software was used to identify cell populations.The data CMF were classified by antigenic expression intensity in the analyzed cells, this classified they are in the clinical reports, according demonstrated to table 1.

Table 1. Classification of antigenic expression intensity according to clinical reports

\begin{tabular}{lc}
\hline Classification & Intensity Expression \\
Weak Expression & $+/-$ \\
Positive of Expression & ++ \\
Lack of Expression & - \\
\hline
\end{tabular}

In this work, the statistical methodology was applied for descriptive frequency epidemiology analysis from obtained data, where the average frequencies, medians, as well as the respective confidence intervals were calculated by the program.

The statistical tests Non-parametric Wilcoxon and Mann-Whitney were also applied for the association between the variables presented by the patients. The overall survival were calculated by the KaplanMeier method and compared by the log-rank test. For statistical purposes, a value of $p<0.05$ was considered as a significant probability.

This work was accomplished in accordance with the terms of resolution $466 / 12$ of Conselho Nacional de Saúde. Submitted and approved by Comitê de Ética e Pesquisa (CEP) - ICS, through the Plataforma Brasil and with technical advice/ resolution number 10205918.6.0000.5662.

\section{RESULTS}

\section{Demographic Characteristics}

Diagnosis of ATLL is relatively uncommon in frequency, so this laboratory in Bahia identifies an average of 13 confirmed cases per year. Thus, 110 patient reports were identified between 2010 and 2018 referred to the Service. Of these only 35 (32\%) presented complete information for the analysis proposed by the study. Of the 75 (68\%) patients excluded, it was not possible to obtain medical records from 53 (70.7\%) of them; 22 (29.3\%) were registered with SMART, but there was no information from this patients.

Among the 35 eligible patients selected, 25 lived in Salvador-Bahia and 10 were from neighboring cities from Salvador city. Those who reported living in Salvador, this were from the outskirts of the city. Between patients evaluated, 54.3\% were female and $45.7 \%$ male. In men had a mean age of approximately 52 years and women 49 .

\section{Clinical features}

The clinical forms of ATLL was manifested different between the sexes: in men there was a higher frequency for chronic form (14.28\%), followed by acute (8.57\%), lymphomatous (8.57\%) and smoldering $(2,85 \%)$, and in $11.42 \%$ of men did not have classification in the medical record. The women exhibit that the manifestation acute (20\%), smoldering (14.28\%), lymphoma $(8.57 \%)$, chronic $(5.71 \%)$ and tumoral $(2.85 \%)$, and in $2.85 \%$ had no classification in the medical record. Therefore, between the sexes, it is noticed that in women a prevailed the acute manifestations and at the men, chronic manifestations.

The biochemical markers observed and the leukogram were within normal range of reference values for all cases. From biochemical markers, only the LDH showed altered (levels elevated) in most participants. Among the groups evaluated, 14\% of the chronic ATLL individuals had LDH values above the normal range of the reference values (115 and $225 \mathrm{IU} / \mathrm{L}$ ) and $72 \%$ of the participants had values twice above the normal range. The patients with subtype primary cutaneous tumor (PCT) and acute has LDH values twice above normal. From $50 \%$ of patients both subtype the lymphomatous ATLL and the smoldering subtype showed LDH twice above normal, but half at them had LHD normal (33\%) and $17 \%$ of this half had once above of normal levels, as summarized in table 2.

Between the clinical manifestations, skin lesion was observed in all patients, and $57.1 \%$ were of these occurrences only skin lesion. However, some patients presented, besides skin lesions other of pathologies, such as lymph node enlargement (11.4\%), HTLV-Iassociated infectious dermatitis $(\mathrm{DIH})$ and sepsis together $(8.6 \%)$, hepatosplenomegaly and renal dysfunction together (5.7\%), hepatosplenomegaly (5.7\%), adenomegaly (2.9\%) and Tropical spastic paraparesis / HTLV-1 associated myelopathy (HAM / TSP) (2.9\%) and 5.7\% don't had information, figure 1.

\section{Treatment used for this population and proportional distribution of morbidity}

Regarding the treatment used, the most used medical recommendation for this population was the combined administration of interferon (IFN) and zidovudine (AZT) corresponding to $31.4 \%$ of the cases, $p<0.001$. The second strategy was the medication using four drugs; cyclophosphamide, doxorubicin, vincristine and prednisone, a therapy known as $\mathrm{CHOP}$, consistent with $17.1 \%$ of cases. The third therapeutic resource observed was the combined use of IFN, AZT and CHOP (11.4\%) and $5.7 \%$ didn't receive treatment due to medical advice and $28.6 \%$ of clinical records don't have therapeutics information (figure 2).

In the overall survival analysis of the cases there were 17 (48.57\%) dead and 18 (51.42\%) living. Deaths were more frequent in patients with acute ATLL subtype (53\%), an outcome that was not observed in the group of patients with form (33\%). However, the patient with subtype primary cutaneous tumor (PCT) survived only one month after diagnosis. The 
Table 2 - Demographic and clinical characteristics of patients with ATLL.

\begin{tabular}{lccccc}
\hline Status & Chronic & Acute & Limphomatous & PCT & Smoldering \\
\hline LDH ( LEVELS) & - & - & & & \\
Normal & - & - & $33 \%$ & - & $33 \%$ \\
$<2$ x of normal & $14 \%$ & - & $17 \%$ & - & $17 \%$ \\
$<2$ x of normal & $72 \%$ & $100 \% *$ & $50 \%$ & $100 \% *$ & $50 \%$ \\
\hline
\end{tabular}

Subtitle: primary cutaneous tumor (PCT); lactate dehydrogenase (LDH); $\mathrm{p}<0,005{ }^{(*)}$

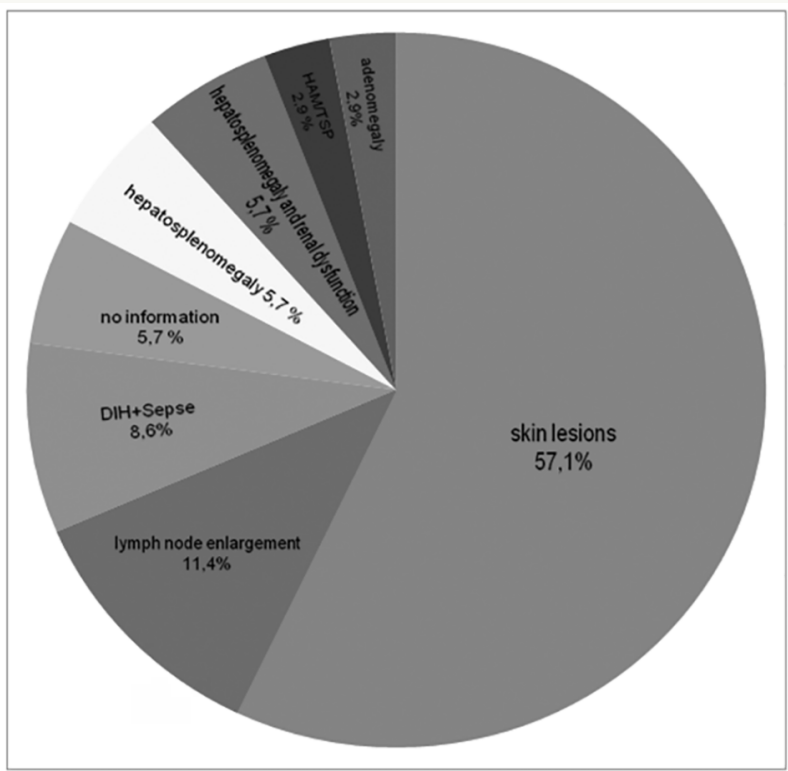

Figure 1 - Frequency of pathological disorders induced by ATLL



Figure 2 - The treatments used in the studied population

median survival rate was 11 months. The PCT (1 month) and acute ATLL (9.5 months) and smoldering ATLL (11.5 months), log-rank $p<0.001$, figure 3.

\section{Flow cytometric analysis}

The data analyzed come from the mean fluorescence intensity (MFI) of anomalous T cells from a peripheral blood sample. For all clinical forms of ATLL there was a total loss of the CD8 marker. In the evaluation of the CD7 molecule, partial loss was observed in 50\% of patients with chronic and smoldering forms, which was absent in other cases. A partial reduction in CD3 expression was detected in all patients groups, which was more observed in the acute $(14,28 \%)$ e smoldering $(11,42 \%)$ subtype. Only PCT group os patients had normal expression for this molecule. There was a partial reduction of marker CD25 only for the group PCT. It was observed that only the subtype acute presented partial loss of the CD5 molecule (14.28\%). Data presented in table 3.

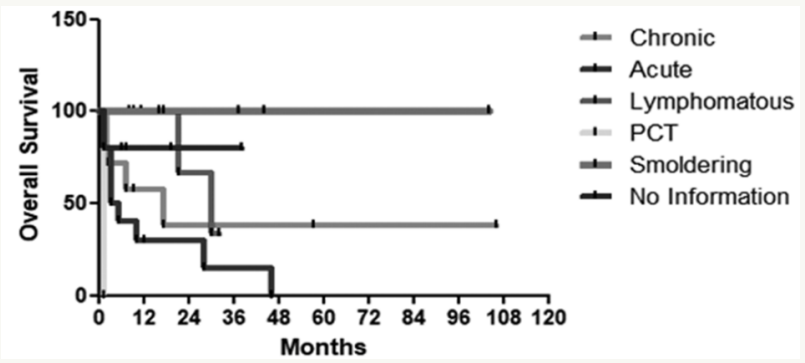

Figure - 3: Overall survival of patients with ATLL according to clinical subtype

\section{DISCUSSION}

According to the findings of Arisawa et al. (2000) and Carneiro-Proietti et al. (2002) the first signs of clinical manifestations of ATLL begin with older age, with the apex of its pathological expression between 40 - 60 years of age, which was consistent with the age range observed in the studied population. The development and expression of this hematological disease after the fourth decade of life is a result of the viral incubation time, aswell as the weak induction of the immune system during this long latency period, thus enabling the clonal expansion of the affected cells, as well as accumulation of mutations and cellular transformation ${ }^{14}$.

In 2006, Mota et al. highlighted that the low socioeconomic power, older individuals and females are some risk factors for the pathological development of HTLV-1 and these characteristics are similar to the profile of the population evaluated. Thus, the present study suggests that women have a slight tendency to develop ATLL, just as they have clinical manifestations a few years earlier than men.

In the present study, the women was more often for acute clinical manifestation and smoldering. The acute condition is reported as one of the most aggressive categories of ATLL and the smoldering condition, also called indolent is referred to as an intermediate stage between an patient asymptomatic HTLV-1 or with monoclonality, as this condition may have no symptoms for many years 13,14,16.

However, according to Carneiro-Proietti et al. (2002), the smoldering form may evolve to the acute form that is characterized by the presence of mature and immortalized CD4+ T cells. However, it is not known the causes that can trigger each clinical form of ATLL, but Yamagishi \& Watanabe (2012) indicate that genetic and environmental factors may favor clinical development.

It was also observed that ATLL form with the best overall survival was smoldering with longer survival 
Table 3 - Comparison between clinical subtypes and MIF of anomalous T cells.

\begin{tabular}{|c|c|c|c|c|c|}
\hline \multirow[t]{2}{*}{ Cluster of differentiaton } & \multicolumn{5}{|c|}{ Antigenic expression of ATLL subtype } \\
\hline & Chronic & Acute & Lymphomatous & $P C T$ & Smoldering \\
\hline CD45 & + & + & + & + & + \\
\hline CD4 & + & + & + & + & + \\
\hline CD3* & $+/-$ and + & $+/-$ & $+/-$ and + & + & $+/-$ \\
\hline CD25* & + & + & + & $+/-$ & + \\
\hline CD8 & - & - & - & - & - \\
\hline CD2 & + & + & + & + & + \\
\hline CD7* & $+/-$ and + & - & - & - & $-/-$ and - \\
\hline CD5* & + & $+/-$ & + & + & + \\
\hline
\end{tabular}

Subtitle: primary cutaneous tumor (PCT); CD: Cluster of Differentiation. The MIF data are structured characterized according to the reports, in which (+/-) Weak antigenic expression; $(+)=$ Positively antigenic expression; $(-)=$ Absence of antigenic expression. ${ }^{*} \mathrm{P}<0.001$.

period and less associate with aggressive clinical conditions, so with the study by Akbarin et al. (2017). The acute form presented the highest death rate and one of the shortest survival times, as well as the PCT subtype. This outcome was similar to the results reported by Malpica et al. (2018) and this information is consistent with ATLL natural history.

Both the chronic and acute group, as for the PCT group, presented high levels of $\mathrm{LDH}$, emphasizing that the last group had the highest level of LDH, when compared to the others. The high level of LDH may be linked to more aggressive symptoms and directly related with the evolution of the disease, which is consistent with the findings of the present assessment, thus proposing that high levels of LDH may be a good indicator evolution and clinical aggressiveness $6,18,19,20$. It is important to highlight that in ATLL there is skin involvement and that it can occur in any clinical condition, be it less or more aggressive. These skin manifestations may appear in various forms and in some cases may affect other organs $^{1}$. In all the cases studied the individuals had dermatological lesions and in half of the cases evaluated, they were associated with another clinical condition. These showed advanced and aggressive ATLL form, which indicates that the clinical condition is an indicator of death evolution, as was also observed in the study by Akbarin et al (2017).

The HTLV-1 is known to cause immunosuppression of the immune system and when associated with other pathogens, such as opportunistic diseases, which are commonly reported in cases of ATLL, may indicate immune deficiency. Generally, individuals that denote these characteristics present more intense conditions and rapid evolution of the disease ${ }^{13,18}$. Evidence has shown that ATLL does not contain somatic mutant genes, which could explain its aggressiveness. However, it is evident that diseased cells have multiple molecular characteristics, such as genome deregulation and gene regulation, which are determinant factors for disease progression ${ }^{10}$.

It was observed a distinct pattern in the expression of molecular markers among ALL clinical pictures, suggesting that such behavior may reflect the pathway of clinical pathogenesis. It is generally observed that the ATLL phenotype is known to present simultaneous positivity for CD4 + CD25 +, as observed in the present study ${ }^{6,14}$.

The CD25 surface marker is the cytokine receptor IL2. Was reported that IL-2 was not observed in their analysis for ATLL patients, as for this population there is an overexpression of this cytokine, which is involved in several signaling pathways that contribute to ATLL ${ }^{17}$. However, in the present study, it was observed that for individuals with PCT was partial loss of CD25, indicating that there is a reduction in the presence of $\mathrm{T}$ helper lymphocytes, because one of the characterizations of this cell group is the expression of this marker. Chen et al (2010), report that the expression of peripheral blood surface marker molecules for some ATLL types can be produced independently of cytokines and in vitro these cells needed co-culture.

In the evaluation of the other markers were consistent with the study by Bazarbachi et al. (2011) and this group also reports that in cases of ATLL there is loss of expression of CD7 marker. The expression of HTLV-1 specific CD8 + T cells is described as mainly responsible for clearing infected cells and controlling viral load, however there is a possibility of inhibition of tax gene expression as an immune system escape mechanism ${ }^{24}$. Thus, it was shown that the frequency of tax-specific CD8 + cells were lower in individuals with ATLL ${ }^{23}$.

There was a tendency for combined the therapy administration of IFN and AZT, assuming that this therapeutic scheme was chosen, as the literature indicates that this form of treatment results in a better therapeutic response with a high initial response rate and possible survival control, which is often significantly longer ${ }^{18,21,24}$.

This study presents an epidemiological and immunophenotypic evaluation for the specific population evaluated, which came from the public services offered by Labimuno, with SUS support. The number of cases was reduced to 35 , because this 
study required medical records, however many of them were not found on the SMART platform. Thus, there was a limitation in the sample number of the study, but as the evaluated population is considered rare, the statistical frequency presented confidence levels for the retrospective evaluation.

\section{CONCLUSION}

The present study concludes that individuals with ATLL presenting the clinical forms: acute and PCT may evolve faster for death, unlike the smoldering subtype. Death outcomes were more frequent in women, and in cases who presented T circulating cell clone of CD4 subpopulation and CD7 loss expression, as well as partial loss of CD5 and CD25. Treatment using the combination of IFN and AZT was the better therapy.

\section{ACKNOWLEDGMENT}

This work was supported structurally by the Laboratório de imunologia e imunodiagnóstico - Labimuno UFBA-ICS and financially by the Coordenação de Aperfeiçoamento de Pessoal de Nível Superior- CAPES.

\section{REFERENCES}

1. Oliveira, Pedro Dantas; Farre, Lourdes; Bittencourt, Achiléa Lisboa. Adult T - Cell Leukemia/Lymphoma. Revista Da Associação Médica Brasileira, v. 62, n. 7, p. 691-700, 2016

2. Pombo-De-Oliveira, Maria $\mathrm{S}$. et al. Adult T-cell leukemia/lymphoma and cluster of HTLV-I associated diseases in brazilian settings. Leukemia \& Lymphoma, v. 42, n. 1-2, p. 135-144, 2001

3. Matsuoka, Masao. Human T-cell leukemia virus type I (HTLV-I) infection and the onset of adult t-cell leukemia (ATLL). Retrovirology, v. 2, n. 1, p. 27, 2005.

4. Clark, Georgina et al. CD nomenclature 2015: human leukocyte. Journal of Immunology, v. 195, p. 4555-4563, 2015.

5. Bittencourt, Achiléa L. et al. Adult T-cell leukemia/ lymphoma (ATL) presenting in the skin: clinical, histological and immunohistochemical features of 52 cases. Acta Oncologica, v. 48, n. 4, p. 598-604, 2009.

6. Akbarin, Mohammad Mehdi et al. Evaluation of the role of tax, hbz, and HTLV-1 proviral load on the survival of ATLL patients. Blood Research, v. 52, n. 2, p. 106-111, 2017

7. Tsukasaki, Kunihiro et al. Definition, prognostic factors, treatment, and response criteria of adult t-cell leukemia-lymphoma: a proposal from an international consensus meeting. Journal of Clinical Oncology, v. 27, n. 3, p. 453, 2009.

8. Paiva, Arthur; Casseb, Jorge. Origin and prevalence of human T-lymphotropic virus type 1 (HTLV-1) and type 2 (HTLV-2) among indigenous populations in the americas. Revista do Instituto de Medicina Tropical de São Paulo, v. 57, n. 1, p. 01-14, 2015.

9. Chen, Jing et al. Autocrine/paracrine cytokine stimulation of leukemic cell proliferation in smoldering and chronic adult T-cell leukemia. Blood, v. 116, n. 26, p. 5948-5956, 2010.
10. Yamagishi, Makoto; Watanabe, Toshiki. Molecular hallmarks of adult $T$ cell leukemia. Frontiers in Microbiology, v. 3, p. 334, 2012.

11. Shimoyama, Masanori; Iymphoma study group (1984-87). Diagnostic criteria and classification of clinical subtypes of adult T-cell leukemialymphoma: a report from the lymphoma study group (1984-87). British Journal of Haematology, v. 79, n. 3, p. 428-437, 1991.

12. Arisawa, Kokichi et al. Evaluation of adult Tcell leukemia/lymphoma incidence and its impact on non-Hodgkin lymphoma incidence in southwestern japan. International Journal of Cancer, v. 85, n. 3, p. 319-324, 2000.

13. Carneiro-Proietti, A. B. et al. Infecção e doença pelos vírus linfotrópicos humanos de células T (HTLV-I/II) no Brasil. 2002.

14. HTLV. Carneiro-Proietti, A. B. 6.ed. atual. e aum. Belo Horizonte: FUNDAÇÃO HEMOMINAS, 2015. 651 p. : il. ; - (Cadernos Hemominas; v. 16)

15. Mota, Augusto et al. A case-control study of HTLVinfection among blood donors in Salvador, Bahia, Brazil-associated risk factors and trend towards declining prevalence. RevistaBrasileira deHematologia e Hemoterapia, v. 28, n. 2, p. 120-126, 2006

16. Bittencourt, Achiléa L.; Farré, Lourdes. Adult T-cell leukemia/lymphoma. Anais Brasileiros de Dermatologia, v. 83, n. 4, p. 351-359, 2008.

17. Yamagishi, Makoto et al. Polycomb-mediated loss of mir-31 activates nik-dependent nf-kb pathway in adult $t$ cell leukemia and other cancers. Cancer Cell, v. 21, n. 1, p. 121-135, 2012.

18. Malpica, Luis et al. epidemiology, clinical features, and outcome of HTLV-1-related ATLL in an area of prevalence in the united states. Blood Advances, v. 2, n. 6, p. 607-620, 2018.

19. Borducchi, Davimar Miranda Maciel; Kerbauy, José; De Oliveira, J. S. R. Linfoma/leucemia de células $\mathrm{T}$ do adulto. Revista Da Associação Médica Brasileira, v. 45, n. 1, p. 63-70, 1999

20. De Oliveira, Ms Pombo et al. Adult T-cell leukaemia/ lymphoma in brazil and its relation to htlv-1. The Lancet, v. 336, n. 8721, p. 987-990, 1999.

21. Bazarbachi, Ali et al. Meta-analysis on the use of zidovudine and interferon-alfa in adult t-cell leukemia/lymphoma showing improved survival in the leukemic subtypes. Journal Of Clinical Oncology, v. 28, n. 27, p. 4177-4183, 2010.

22. Vallve, Maria de Lourdes Farre et al. patogênese da leucemia/linfoma de células T do adulto (ATL). 2009

23. Kozako, Tomohiro et al. Reduced frequency, diversity, and function of human t cell leukemia virus type 1-specific cd8+ $T$ cell in adult $T$ cell leukemia patients. The Journal of Immunology, v. 177, n. 8, p. 5718-5726, 2006.

24. Laher, Abdullah E. et al. HTLV-1, ATLL, refractory hypercalcaemia and HIV-1 co-infection. Oxford Medical Case Reports, v. 2018, n. 1, p. omx081, 2018. 